\title{
The potential to reduce the risks posed by tailings dams using satellite-based information
}

\author{
Darren Lumbroso¹, Caitlin McElroy², Craig Goff'1, \\ Marta Roca Collell ${ }^{1}$, Gregor Petkovsek ${ }^{1}$, Mark Wetton ${ }^{1}$
}

1 HR Wallingford, Howbery Park, Wallingford, Oxfordshire OX10 8BA, UK

2 Smith School of Enterprise and the Environment, Oxford University, UK

Corresponding author: Darren Lumbroso, d.lumbroso@hrwallingford.com.

The original version of this paper was published in the International Journal of Disaster Risk Reduction, Volume 38, August 2019. The DOI is: https://doi.org/10.1016/.i.jdrr.2019.101209

\section{Abstract}

The failures of tailings dams, used to store waste from mining operations, pose a significant risk to the health of people and the environment, especially in many low income countries where the extractive industry makes a significant contribution to the nation's wealth. Recently the rate of failure of tailings dams has increased. The demand for raw materials and increases in intense rainfall as a result of climate change will exacerbate this issue in the future. The monitoring of tailings dams is essential to reduce their probability of failure. Virtually all the recent tailings dams failures were preventable. However, there is generally a lack of transparency and accountability for these structures by mining companies. In the past 10 years an increase in the global coverage and accuracy of Earth Observation (EO) based information has made it technically possible to use EO-based data to remotely monitor critical aspects of tailings dams, such as their deformation and the leakage of pollutants. This paper describes the development of an EO-based service, being piloted in Peru, which would allow tailings dams to be monitored cost effectively, and also help to forecast any potentially risk inducing behaviour from tailings dams several weeks in advance. Many regulatory bodies in low income countries do not have the resources to adequately monitor mining operations. A low cost EO-based system could improve the transparency and safety of tailings dams, allowing timely preventative interventions to be made where the probability of failure is found to be high.

\section{Keywords}

dam failure; mining; satellites; tailings dams 


\section{Introduction}

There are more than 100 countries worldwide where minerals and metals are extracted by large and small mining companies to satisfy industrial demand [1]. Amongst these countries, there are more than 50 that can be considered "mining countries", this is where the mining sector is highly relevant domestically, either because it primarily serves large domestic markets, such as in the United States, or because it employs millions of workers, such as in China or India [2]. In some countries, mining provides an important proportion of the national wealth, with more than $50 \%$ of exports and around $10 \%$ to $20 \%$ of Gross Domestic Product (GDP) [3]. Many of these countries are low and middle income economies. In South America the economies of Bolivia and Peru are particularly reliant on mining [1].

Mining companies are facing increasing pressure to demonstrate what activities they are currently undertaking to minimise environmental damage, improve safety, embrace diversity and contribute to the communities in which they operate [4]. They are also under intense scrutiny to demonstrate how these challenges will be addressed in the future and how they are being incorporated into their overall business strategy [4]. There is need for reliable and affordable information by third parties so that they can monitor compliance of mineral processing companies with safety and environmental regulations, especially where their operations are spread over large areas and are in remote locations.

In the past decade there has been an increase in the global coverage and accuracy of satellite imagery and sensors [5]. This paper presents an ongoing project developing a tool that uses satellite-based data to improve the transparency and accountability of the mining industry with respect to the management of tailings dam, that form part of many mining operations. A consortium of organisations, named in the acknowledgements, are collaborating to develop Earth Observation (EO) based methods for monitoring various aspects of tailings dams, building on existing research that has yet to be commercialised. These methods are currently being piloted in Peru. This is discussed on Section 7.

The failure of a tailings dam at an iron ore mine near the town of Brumadinho in Brazil in January 2019 is a stark reminder of the risks posed by mining operations. Current estimates of the loss of life are around 240 people with others still missing. It is also thought that about 12 million cubic metres $\left(\mathrm{m}^{3}\right)$ of waste materials were released into watercourses, with the potential to contaminate $300 \mathrm{~km}$ of river, damaging ecosystems and destroying the livelihoods of the people reliant on them [6]. Union representatives stated that the disaster was "premeditated" and that there had been long-standing warnings concerning the structural integrity of the tailings dam. The owners of the mine, Vale SA, have denied these charges and stated the mine was up-to-date and designed to the latest standards [6]. Tailings dam failures are often described as "unforeseeable" or "unavoidable" by the mining industry [7]. However, shortcomings in the storage and management of tailings, post-processing metal wastes and hydrocarbons are the largest source of high public consequence failures worldwide [7]. Given the increasing urgency of addressing tailings dam failures, although the work presented in this paper is at an early stage, it is important to demonstrate and raise awareness of the potential for risk reduction using EO data, as well as expanding the opportunities for transparency in risk monitoring for tailings storage facilities and other infrastructure that pose risks to people and to the environment. 


\section{A brief history of recent tailings dams failures}

Tailings dams are earth embankments used to store mine waste and can be more than $100 \mathrm{~m}$ high. Tailings are the by-product of mineral processing and are mixtures of crushed rock and processing fluids that remain after the extraction of economic materials from the mine resource [8]. Tailings are generally stored on the surface either behind retaining structures (tailings dams), in the form of piles (dry stacks), or as landscaped hillside slopes [9]. They can also be stored underground in mined out voids by a process commonly referred to as backfill or as paste tailings ${ }^{1}[10]$.

Tailings dams are often constructed with readily available materials. Unlike water storage dams, the construction phase of a tailings dam continues for the operating life of the mine processing plant. The raising of the dam crest level occurs frequently over its lifetime as the build-up of stored tailings behind the dam increases. Sometimes this process lasts several decades with many changes in operation and design parameters occurring during this period. A photograph of a typical tailings dam is shown in Figure 1. Tailings dams are often constructed with steep slopes to reduce the volume of material needed, and by using the placed and compacted tailings to save on material costs ${ }^{2}$. Keeping these structures intact over many decades is challenging. In the context of long-lived infrastructure ${ }^{3}$, their rate of failure is high, owing to inadequate design regulations and less rigorous construction and supervision methods than for normal water-retaining dams, especially in low-income countries [7].

Tailings dams are particularly prone to failure owing to:

- A lack of rigorous design regulations, especially in low income countries [11];

- Construction of the embankment with less than ideal materials, including residual materials from the mining operations [12];

- Less rigorous construction methods (e.g. inadequate compaction) than for normal dams [11];

- Steeper embankment slopes than normal water-retaining dams for reasons of cost and/or space [13];

- Sequential increases in the height of the embankment which can result in zones of lower shear strength [14];

- Prohibitively high maintenance costs after mineral processing operations have ceased and a lack of clarity over/acceptance of responsibility [15].

${ }^{1}$ Paste tailings have a higher density and lower moisture content than "normal" tailings. This means that if a tailings dam is required it is smaller than one needed to accommodate less dense and moister tailings. Paste tailings offer significant economic and environmental benefits compared to conventional methods of storing tailings [10].

2 Tailings dams are usually constructed using only a specific fraction of the tailings stream that is suitable for a specific purpose. Other materials are also used for specific elements of the tailings dam including compacted clay cores, crushed stone for drainage elements and dense native soils for abutments. Reinforcing elements such as geotextiles may also be used.

${ }^{3}$ These are pieces of infrastructure that usually need to be maintained for a significantly greater number of years (e.g. from 50 years to in perpetuity) than most other capital assets 

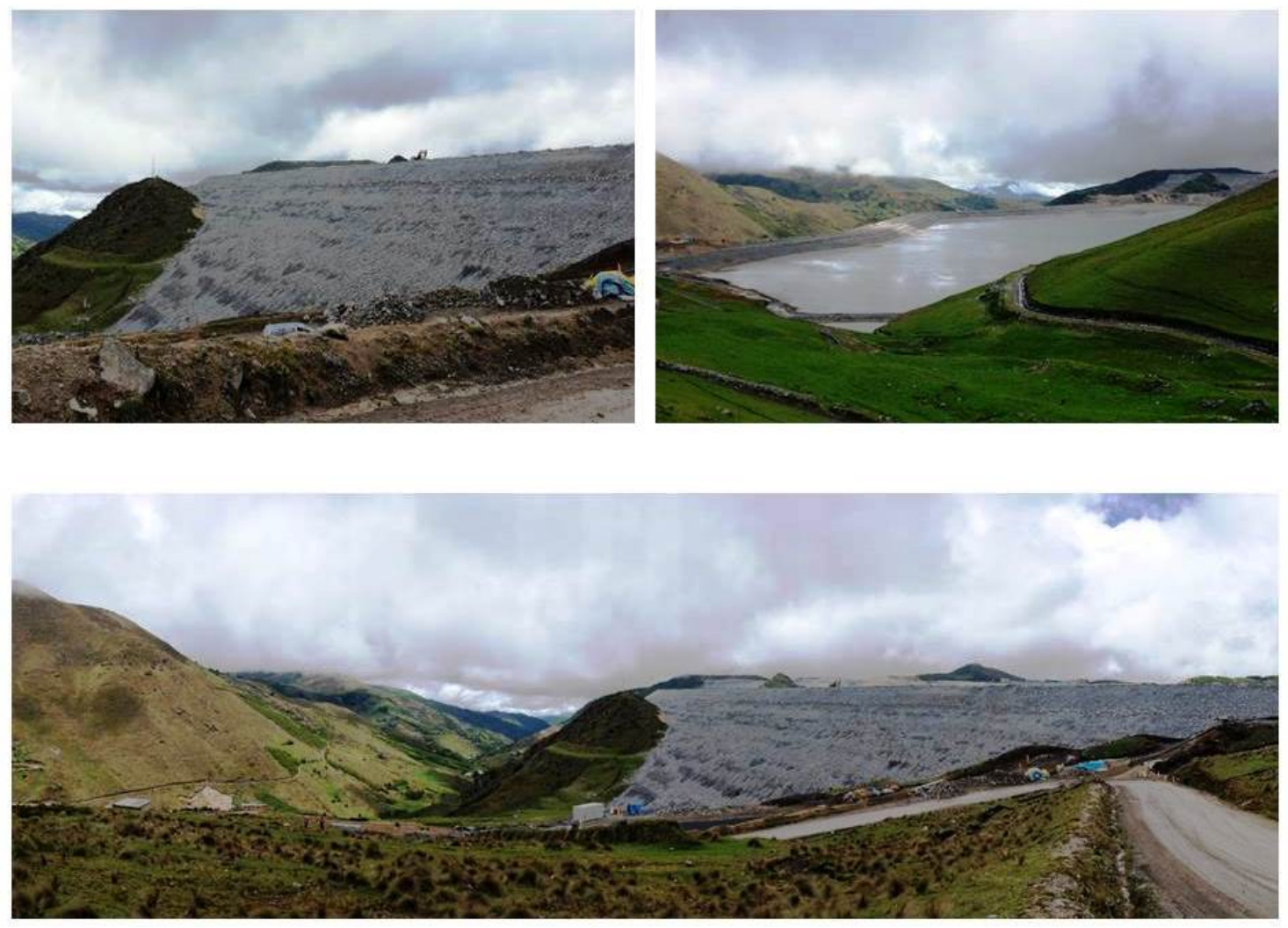

Figure 1 Photographs of a tailings dam in Peru showing the downstream face, tailings pond and a panorama of the valley downstream of the dam

The rate of tailings dam failures is increasing, with $50 \%$ of serious tailings dam failures in the last 70 years occurring between 1990 and 2010 [16]. In South America alone there are approximately 1,200 mines currently in operation which have tailings dams, in addition to many thousands of tailings dams that have been abandoned and/or which are no longer operational. Some studies estimate that the number of mining sites in the world is of the order of 18,000 [16] or 30,000, according to a more recent source [17]. However, there is not an accessible, accurate global inventory of tailings dams. The National Inventory of Dams (2019) indicates that there are over 1,400 tailings dams in the USA [18], and in the year 2000 the worldwide total was estimated at over 3,500 [19]. In addition to tailings dams, it is probable that a very large number of other small operating tailing storage facilities are not monitored including many non-operational large and small facilities.

The challenges in estimating the actual number of global tailings facilities are illustrated by China. In 2016 Wei at al. reported that in China the introduction of environmental legislation in 1989, requiring the construction of tailings ponds, led to a significant increase in tailings storage facilities and by 2000 there were more than 6,000 of these structures [20]. Since 2000 an expansion of the mining industry as a result of China's rapid economic development has meant that in 2008 there were estimated to be more than 12,000 tailing storage facilities in the country [20]. A newspaper article in 2011 reported that the Chinese Ministry of Environmental Protection estimated that $17 \%$ of these are in a "poor" or "dangerous condition" [21]. Most tailings dam safety management in China is based on experience owing to a lack of effective monitoring 
tools [20]. While there are large discrepancies in accounting for the exact number of tailings dam globally, it is clear that the multitude of tailings dams that are liable to failure is more significant than often considered [17].

Over the past decade there have been a number of significant tailings dam failures worldwide that have affected tens of millions of people both directly and indirectly (see Table 1). Intense rainfall events have been linked to $25 \%$ of global and $35 \%$ of European tailings dam failures [15]. Climate change will increase the frequency of extreme rainfall events even in regions where the average annual rainfall is predicted to decrease [22]. This increase in rainfall intensity is likely to increase the probability of failure of tailings dams in the future, making the downstream ecosystem services on which many of the poorest people in these regions rely, become increasing vulnerable.

There is a need for a cost effective way to remotely monitor tailings dams to help predict potentially catastrophic failures, as well as leaching of contaminants downstream. This paper outlines the risks posed by tailings dams and then articulates how a satellite-based monitoring system currently under development could decrease the impacts of tailings dam failures by providing increased real-time risk information, thirdparty access to monitoring data, and warnings to nearby communities. A critical aspect of this is the way in which, satellite-based monitoring has the ability to be used by a wide range of stakeholders, beyond just mining companies, in reducing the probability of tailings dam failures. 
Table 1: The impacts of major tailings dam failures since 2009

Tailings dam name,

country, year of failure Human impacts

Córrego de Feijão mine, At least 237 fatalities and some 50 people missing

Brumadinho, Região, Livelihoods of hundreds of thousands of people affected

Minas Gerais,

Brazil, 2019

Samarco Mineração SA, At least 19 fatalities

Minas Gerais, Brazil,

2015

800 buildings affected and some 200 destroyed

Water supply of at least 300,000 people polluted

Livelihoods of one million people affected

11,000 people reliant on fisheries as their primary source

of nutrition affected

Affected power production at the Candonga hydropower plant

Herculano Mineração

At least three fatalities

Ltda, Minas Gerais

Brazil, 2014

Buenavista del Cobre,

Pollution of rivers affected the water supplies of at least

Cananea, Mexico, 2014

\section{4,000 people}

\section{Environmental impacts}

\section{Other impacts}

Pollution of watercourses at

Reduction in Vale's share price by least $300 \mathrm{~km}$ downstream of $24 \%$ losing US\$19 billion in market the site.

capitalization

Vale's licence to operate its Jangada mine revoked

Minas Gerais Government gave the mine operators three years to decommission up to 50 tailings dams upstream of the site

35 to 55 million $\mathrm{m}^{3}$ of mining waste released polluting some $660 \mathrm{~km}$ of rivers 1,500 ha of natural reserves polluted

Destruction of fisheries

Beaches on the Espírito Santo coast polluted and closed to the public

Significant damage to the downstream environment estimated to have had a cost of at least US\$8 million

$40,000 \mathrm{~m}^{3}$ of copper sulphate and heavy metals polluted the Sonora and Bacanuchi rivers
BHP share price hit a ten year low Legal proceedings including charges of homicide filed against 21 executives of Vale and BHP Billiton

Herculano mine partners indicted on first degree murder charges

Fine of US\$43.5 million imposed on the mining company

Owners fined US\$1.8 million and million to a trust fund to provide compensation for the economic and environmental damage and health problems caused in the downstream communities agreed to contribute US\$154 
Tailings dam name,

country, year of failure

Mount Polley, British

Columbia, Canada

2014

Pollution of drinking water affected at least 300 residents

Environmental impacts

Elevated levels of selenium

in fish exceeded guidelines

for human consumption

Mercury levels were found to be nine times higher than

Obed Mountain Coal

Mine, Alberta, Canada,

2013

Philex, Benguet,

Philippines, 2012

normal in the Athabasca River, while Polycyclic Aromatic

Hydrocarbons were at levels four times higher than the

Canadian standard for potable water

Livelihoods of communities who lived downstream of the site who were reliant on fishing were destroyed

Talvivaara Mine,

Finland, 2012

Deterioration in drinking water quality downstream

Kolontár,

10 fatalities and 150 people injured

Hungary, 2010

Extensive flooding downstream

Magadan,

Two fatalities

Russia, 2009

11 homes destroyed

Huayuan, Xiangi,

Three people killed and four injured

China, 2009
$760,000 \mathrm{~m}^{3}$ of coal waste and

slurry released into the

20 million $\mathrm{m}^{3}$ of copper tailings released

Balog Creek declared "biologically dead"

Fish kills downstream

$700,000 \mathrm{~m}^{3}$ of mining waste released

High $\mathrm{pH}$ of the waste

contaminated rivers and the soil downstream over $8 \mathrm{~km} 2$

1.3 million $\mathrm{m}^{3}$ of mining waste released polluting downstream watercourses

Pollution of downstream watercourses
Athabasca River system
Other impacts

Company's share price fell from

US $\$ 16.56$ to US $\$ 9.70$ per share; a market capitalization decline of more than US $\$ 500$ million dollars $(41 \%)$ in one trading day

The Alberta Energy Regulator corporation filed charges against the mine's operators

Department of Environment and Natural Resources imposed a fine of US\$20 million on the mining company

The disaster played a large part in the mining company who owned the site going bankrupt, with a $€ 1.4$ million debt outstanding

The clean-up costs were estimated to be tens of millions of US dollars

Strengthening of environmental legislation post-event

Not available

Source: [23] [24] [25] [26] [27] [28] [29] [30] [31] [32] [33] 


\section{The mechanisms and probability of tailings dam failures}

This section briefly outlines the main mechanisms and the probability of failure of tailings dams.

\subsection{Failure mechanisms}

Tailings dams vary greatly in their design and construction methods, the type of tailings they store, their characteristics, how they are operated, maintained, monitored and kept under surveillance. Their effectiveness and safety also depends on their foundation determined by the local geology.

There are numerous ways in which tailings dams can fail. Figure 2 shows the primary modes of failure, including those that can be monitored using EO-based techniques. Tailings dams are constructed over a period of many years and go through several phases (e.g. construction, operation, decommissioning, and closure) so their monitoring requirements are constantly changing. Often those responsible for monitoring of tailings dams are mining company personnel who are already fully committed to operational duties and therefore not suited for undertaking dam surveillance checks. It is also important to note that most tailings dams will require some degree of monitoring "forever". Small mining companies and owners in low and middle income countries are prone to bankruptcy and/or abandoning non-productive mines so there is a need for a cost effective monitoring solution that can be used for these, as well as structures that are currently operational.

\subsection{Probability of failure}

Using an inventory of 18,401 mine sites, the annual probability of failure rate of tailings dams over the past 100 hundred years has been estimated to be $1.2 \%$ [16]. This is more than two orders of magnitude higher than the failure rate of conventional water retention dams, which is reported to be $0.01 \%$ in terms of annual probability [34]. Water retaining dams are usually regarded as assets, typically for common use, while tailings storage facilities are seen as a cost or liability (i.e. a means of storing waste rather than providing a service) [17].

Since the early 1990s there have been around 20 tailings dam failures per decade [9]. Table 1 provides an overview of the impacts of major tailings dam failures since 2009. However, failures predominantly occur in small to medium size tailings dams that are up to $30 \mathrm{~m}$ high and contain a maximum tailings volume of 5 million $\mathrm{m}^{3}$. Once a dam fails, the released tailings generally amount to about one-fifth of those contained within the facilities [16]. Other more conservative sources estimate probabilities of failure as more than ten times more likely than other conventional dams retaining water [35], but the difference between both types of structures is still large owing to many of the reasons outlined above. 


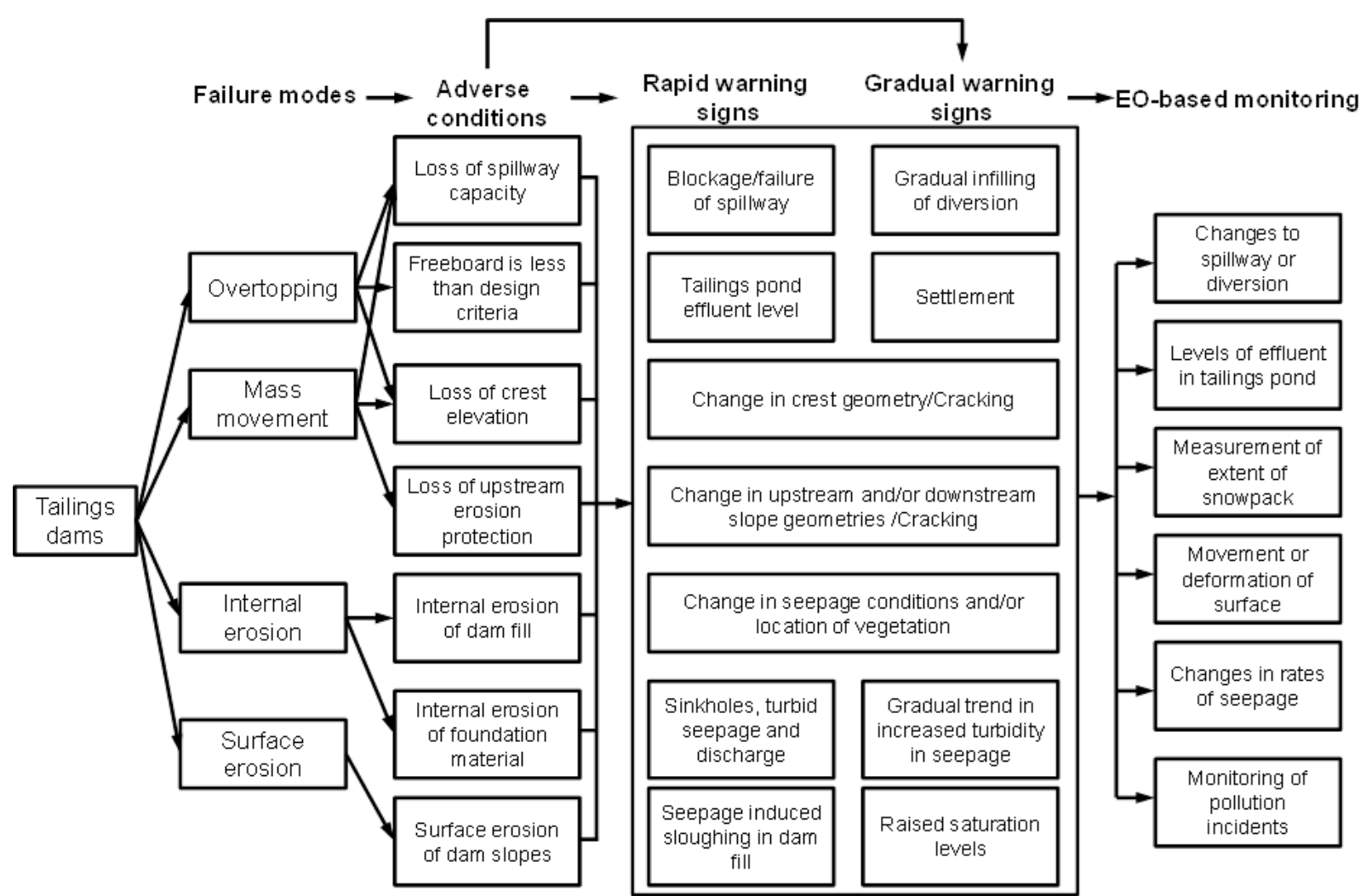

Figure 2 Tailings dam failure modes, warning signs and Earth Observation (EO) based monitoring measures

(Source: Adapted from [12])

\section{Quantifying the risks posed by tailings dams}

The risk posed by tailings dams can be categorised into human, environmental and financial. In the past 20 years there have been a number of tailings dams incidents that have led to a significant loss of life and adversely affected the livelihoods of hundreds of thousands of people. The impact of these incidents on the environment is significant and often underestimated [36]. The failure of tailings dams also has financial consequences. These are briefly outlined below.

\subsection{Human impacts}

There have been several cases where the failure of tailings dams has led to significant loss of life, which generally occur soon after the event via drowning or suffocation [8]. However, in the medium and long term, the release of contaminants into the food chain and water sources can increase mortality rates [8] [37]. Records indicate that thousands of people have died from tailings dam failures in the past 20 years [8].

The leakage of dangerous chemicals and waste from tailing dams poses a real risk to people. In low income countries, women are disproportionately affected by these disasters owing to several factors [38] [39]. In many low income countries it is generally women who are responsible for collecting water where there is no potable water supply. There is also evidence that contamination of water supplies by mining operations has 
a greater impact on women's health than men's [38]. In many African, Asian and Latin American countries it has been shown that this is because women are in greater contact with water than men because they tend to have the responsibility for collecting it, cooking and doing the laundry [39] [40]. Contamination of local water supplies also requires women to travel further to collect water. The failure of a tailings dam in Mariana in Brazil in 2015 disproportionately affected women because reports of domestic violence multiplied, much of which is due to the increasing incidence of alcoholism among men as a result of the incident [41].

Risk assessments of tailings dams should include credible estimates of the potential loss of life for hypothetical failure events to quantify risk and to assist with making decisions about their construction and decommissioning (see [42]; [43]). Although tools do exist to estimate the loss of life from tailings dams failures (see [42]; [44]), they are rarely employed and in cases where an analysis is carried out, it is relatively simplistic [45]. The health impacts caused by contaminated food, water and soil are also seldom accounted for when assessing the risks posed by tailings dams.

\subsection{Environmental impacts}

The leaching of substances such as arsenic, cyanide or heavy metals causes pollution of both the aquatic and terrestrial environment. The presence of sulphides in the tailings exposed to oxygen and water causes the generation of sulphuric acid, known as acid mine drainage, which can mobilise heavy metals and arsenic. Acid mine drainage is recognised as one of the more serious environmental problems in the mining industry [46]. Many old and abandoned tailings dams were not designed, constructed or operated with an awareness of the environmental impacts of acid mine drainage, and no provisions were made to minimise the generation of acid leachate or to prevent the leachate from entering the groundwater or surface waters. The cost of cleaning up mines has typically been 10 times more than mining industry estimates when acid drainage was involved [47].

In 2000, in Romania, 100,000 $\mathrm{m}^{3}$ of cyanide contaminated water escaped from a gold mine tailing reservoir into the Danube, Someş and Tisza rivers, killing up to $80 \%$ of aquatic life in some of the affected areas [34] [48]. In the case of the Los Frailes mine tailing dam failure in Spain which released 4 to 5 million $\mathrm{m}^{3}$ of pollutants into the Guadiamar River, the watercourse still showed high rates of contamination in certain areas 10 years after the event [8] [49].

A swift clean-up operation can help to minimise the impacts of tailings release in the environment. The Mount Polley mine tailings embankment failure in Canada in 2014, was at the time the largest documented release of mine waste into the environment. Environmental recovery operations were quick. Within a year a significant quantity of the released tailings had been removed from the primary receiving watercourse, the river corridor was stabilised and construction of a new channel had begun [50]. The collected data showed that this limited the chemical impacts on the watershed, as did the fact that both the tailings and the receiving environment were alkaline rather than acid. Nevertheless, some chemical mobilisation still occurred.

\subsection{Financial impacts}

Social and environmental consciousness, as well as investor confidence are now an important part of a mining company's corporate due diligence. Historically, tailings management has been perceived as a component of the "minerals processing circuit" that does not contribute to a mining company's bottom line [29]. However, the management of tailings dams is as critical to a mining company's operational revenue stream, investor confidence, and profit as any other component of the operation. 
A tailings dam "incident", or even the perception of an upset condition or failure can negatively compromise a company's social licence, which is its ability to operate with the permission of, and in cooperation with, its stakeholders at all levels [51]. For example, consequential damages to a company's reputational capital can also have negative implications when it comes to permit applications for future projects. However, the economics of mining limit the resources that are often applied to the construction and operation of the tailings dams.

Direct and indirect costs associated with a tailings dam failure can total billions of dollars. The single most significant economic impact to a mining company is lost market capitalization owing to shareholder stock selloffs. In 2014 a tailings dam at the Mount Polley gold mine in Canada failed and as a result the mining company's stock price fell from US $\$ 16.56$ to US $\$ 9.70$ per share; a market capitalization decline of more than $\$ 500$ million dollars (41\%) in one trading day [29]. In 1995 and 1998, the Omai (Guyana) and Los Frailes (Spain) tailings dam failures caused the owners' market capital to decrease by US $\$ 188$ million and US\$68 million, respectively [29].

The failure of the tailings dam at the Córrego de Feijão mine in January 2019 led to the dam's owners, Vale SA losing more than US $\$ 19$ billion in their market value [6]. The impact created the biggest loss in the entire history of the Brazilian stock market in a single day [6].

\section{Background to the monitoring of tailings dams}

The monitoring of tailings dams, during their construction, operation, decommissioning and closure phases, is essential to reduce their probability of failure. Many tailings dam failure modes (see Figure 2), are preceded by warning signs that can be detected well in advance of them occurring [52]. Tailings dams are generally monitored using two techniques: (i) visual inspections and (ii) in-situ monitoring equipment and there are numerous publications that document these (e.g. see [52] [53] [54]).

It is not possible to determine the actual level of monitoring used by the mining companies globally; however, it appears that many of the large active mines that operate tailings dams are monitoring them using, at the minimum, regular visual inspections. Generally, there is also always some form of in-situ instrumentation monitoring undertaken, which varies from site to site but may for instance include piezometers or drain flows. However, it is probable that a very large number of small operating and non-operating tailings dams are not monitored.

As this paper illustrates, there have been numerous cases of well-monitored tailings dams that have suddenly failed. This is because:

- Potential dam safety risks are not communicated to people in the organisation who have the authority to act;

- Dam safety concerns are not taken seriously enough or ignored because of financial pressures;

- Monitoring is not focused on potential failure modes;

- The quality of monitoring is sometimes poor owing to the equipment used or the capacity of the staff;

- Monitoring is not interpreted by technical specialists and regular independent reviews are not undertaken;

- Regulators do not have the finances or the staff resources to ensure that the conditions relating to dam safety are enforced. 


\section{The development of a satellite-based tailings dam monitoring tool, DAMSAT}

\subsection{Background}

Virtually all the recent tailings dams failures were preventable, either by improvements in their design or by better operational management [7]. However, many regulatory bodies in low income countries do not have the resources to adequately police mining operations. The work this paper presents is a response to the need for a cost effective service so that governments, Non-Governmental Organisations (NGOs) and other stakeholders with limited budgets can monitor both operational and abandoned tailings dams, especially those in remote locations. This would help stakeholders to identify risk "hotspots" and potentially forecast future catastrophic failures, allowing mitigation measures to be put in place in time.

A tailings dam satellite-based monitoring tool using EO data is one step in using emerging technologies openly to dramatically increase transparency, as well as a tool for improving governance of the mining and mineral processing sector. Many governments lack expertise in the technical environmental management of mining operations compared to multi-national mining companies and tools such as this work to level this playing field. Obstacles from wage differences between government and corporations, available training, and the industry-wide dependence on specialist environmental engineering consultancies most often prevent effective government and third-party evaluation of environmental performance and risk at mine sites [55]. As a result, regulators and watchdogs are often bound to the quality and rigor of the reports produced by the mines. Governments face the challenge of overseeing many mines with limited staff numbers who are often less experienced compared to the personnel employed by the mines they are regulating. In addition, even if regulatory bodies have extensive experience of the mining sector, it is challenging for them to stay abreast of the particulars and subtle changes at all the sites they oversee, compared to the miners who operate them on a day-to-day basis. An EO-based monitoring system would help regulators to stay up-to-date with developments at tailings dam sites spread over large areas and in remote locations.

\subsection{Why is a satellite-based monitoring system needed?}

In spite of a basic understanding of the mechanisms that cause tailings dam failures, and a large collection of empirical data on the impact of these failures, tailings dams have continued to fail at a relatively constant rate over the last five decades. In the past three years there have been two major tailings dam failures in Brazil, the consequences of which are shown in Table 1. These mines are owned by two of the largest and richest mining corporations in the world, BHP Billiton and Vale SA. These are firms that have no obvious impediments to use the best available tailings dam monitoring technology presently available. In the case of the 2015 incident in Brazil, public reports and news, have indicated that much was known from ground sensors in 2014 and 2015 about the weaknesses and changes in the tailing dam prior to its collapse [56] [57]. In the 10 hours preceding the full collapse the immediate risk was not communicated to residents who then had very limited time, around 25 minutes in some cases, to flee [57]. The collapse of the Samarco tailings dam killed 19 people, destroyed villages, and harmed the regional water system for the long-term damaging many related livelihoods. 
The example of this disaster indicates that if a mine does not act on the information it has in its possession, that these data also need to be in the hands of those who can and will act to prevent similar events (e.g. regulatory authorities, NGOs). Some have accused the Brazilian authorities of poor enforcement of their environmental regulations in the interest of maintaining the revenues from mining [57]. Whilst this may play a factor, the scale of oversight is also large. For example, in the Minas Gerais region of Brazil where the accident occurred there are an "estimated 750 dams..., 40 of which are considered at risk" [57].

While the large mining firms behind the Samarco operation in 2015 are now being held accountable in legal proceedings and fines of over US $\$ 7$ billion, incidents at smaller sites and involving smaller firms do not have the same recourse. Thus, in many other sites the burden for the human and environmental losses often falls on the state. The risks associated with tailings dams are not limited to sudden, catastrophic failures. There are many tailings dams worldwide that pose a "slow-motion" environmental problem associated with the leaching of harmful substances from them into the environment [58]. These structures may need to be managed in perpetuity, and the remediation and long-term monitoring of these sites is generally not included in the original cost-benefit analysis of the mining operation [58]. They are externalized costs that often only become apparent after the mine has closed or a disaster occurs [58].

Given the highly hierarchical nature of the mining sector, large or "major" firms often account for the greatest volume of revenue from mining in low income countries, but they do not necessarily account for the majority of the nation's mining footprint in terms of physical, environmental, or social impacts. Instead, a multitude of "junior" mine operators of small to medium sized sites operate on exceptionally tight budgets, with a limited amount of capital and with limited reputational risk. Their exploration funding does not come largely from accumulated cash flow from previous production or from the investment income from such funds. They are often characterised by the fact that they have few operational safeguards, because they operate on smaller budgets and have limited reputational risk. Junior miners often lag far behind larger operations in terms of their environmental management and performance [59]. If junior miners do not "strike it rich" before their debt is due, they may have no choice but to file for bankruptcy and abandon their mining operations leaving a legacy of "orphaned" tailings dams.

A recent study indicates that the total portfolio of mines that are not presently viable and are likely to become unviable, without significant new discoveries, may be as high as $30 \%$ to $50 \%$ globally [60], indicating that the number of orphaned tailings dams could increase significantly in the next decade. The increase in marginal mines operated by often less experienced and less financially stable miners poses a difficult challenge to significantly reducing tailings dams failures; hence there is an acute need to monitor junior miners' operations. Existing work (see [61] [62] [63]) has shown that a low-cost tool could improve governance capacity by allowing oversight on an increased number of mine operations of various sizes and thus help to reduce the probability and consequences of failures of tailings dams.

In the past decade the availability and accuracy of EO-based data from satellites has increased considerably. An EO-based remote monitoring system for tailings dams would help to leverage the reach of the usually limited number of government staff responsible for monitoring mining operations over large areas and in locations where it is often challenging and costly to conduct regular site visits. The evidence related to effectiveness of transparency and accountability initiatives within the mining industry is weak [64]. An EObased monitoring system is one tool that could help pave the way to the ultimate goal of zero tailings dam failures. It could also improve transparency and accountability leading to tangible accountability reforms for the management of these structures. 


\subsection{What can satellites monitor?}

It is now technically possible to use EO-based data to monitor critical aspects of tailings dams, such as those shown in Figure 2. Table 2 details the use of satellite-based data for the monitoring of tailings dams. Combining Interferometric Synthetic Aperture Radar (InSAR) and real-time Global Navigation Satellite System (GNSS) can be used to achieve a very high level of automation for tailings dam displacement monitoring that can address a number of inherent challenges for monitoring tailings dams in low income countries. Additionally, optical imagery is a rich source for measurement and detection of various parameters that can indicate issues with operations or stability.

Satellite based information in Table 2 provides a synoptic and comprehensive ability to observe, measure, qualify and quantify over wide areas with a very high frequency. Figure 3 shows the use of EO based data in the context of monitoring aspects of tailings that are directly related to their probability of failure or the chance of a pollution incident.

The high vantage point of space affords a non-invasive solution to monitor large areas, with a relatively high degree of accuracy and precision regardless of the relative inaccessibility and hazardous nature of the terrain that in some cases make in-situ measurement techniques almost impossible. The ability to undertake surveillance with such freedom is important for tailings dams that tend to be in remote locations but also, as a direct result, satellites are able to detect significant changes within tailings dam sites that were not previously under scrutiny or observation. However, much of the EO-based technology is not mature and is not regularly used to monitor tailings dams. The DAMSAT project funded by the UK Space Agency is setting up a prototype system to monitor two tailings sites in Peru.

Some work has been carried out to ground truth the use of EO-based information for a tailings dam failure in Australia (see [63] [65]). On 9 March 2018 a tailings dam at the Cadia gold mine in New South Wales, Australia, failed. Retrospective exercises carried out by both Thomas [63] and Tre-Altamira [65] using InSAR satellite data demonstrated that it is possible to use EO-based data to predict failures of large tailings dams. Figure 4 shows the results produced by Tre-Altamira. Views B and C of Figure 4 show the displacement of the dam before it failed based on EO data and the inverse of velocity method ${ }^{4}$ implemented using the InSAR time series. This work indicates that EO-based information could have made it possible to predict the timing of the failure almost one month before the breach occurred.

\footnotetext{
${ }^{4}$ The basis of the inverse velocity method is to calculate the rate of deformation of the slope of the dam (velocity) and to plot the inverse of the rate of deformation against time (i.e. the inverse velocity against time). As the velocity or rate of deformation increases the inverse will tend towards zero which is when failure occurs. For more details of this method see [66]
} 
Table 2: The use of satellite-based data for monitoring tailings dams

\begin{tabular}{|c|c|c|}
\hline $\begin{array}{l}\text { Type of earth } \\
\text { observation } \\
\text { technology }\end{array}$ & Data provided & $\begin{array}{l}\text { Use of the EO-technology in the } \\
\text { context of tailings dams }\end{array}$ \\
\hline $\begin{array}{l}\text { Interferometric } \\
\text { Synthetic } \\
\text { Aperture Radar } \\
\text { (InSAR) }\end{array}$ & $\begin{array}{l}\text { Relative displacement of the dam or } \\
\text { structure to an accuracy of } 2 \mathrm{~mm} \text { to } 3 \mathrm{~mm} \\
\text { Assessment of water extent. } \\
\text { Digital Terrain Model (DTM) creation }-0.5 \\
\mathrm{~m} \text { horizontal resolution DTMs with } 10 \mathrm{~cm} \\
\text { vertical resolution and absolute } \\
\text { accuracies approaching } 3.5 \mathrm{~m} \text { with no } \\
\text { ground control. }\end{array}$ & $\begin{array}{l}\text { Monitoring of abnormal deformation of the } \\
\text { structure. } \\
\text { Monitoring of movement of the natural } \\
\text { ground in key areas of risk such as at the } \\
\text { abutments of the dam or the reservoir rim. } \\
\text { Assessment of tailings and water levels. }\end{array}$ \\
\hline $\begin{array}{l}\text { Optical-based } \\
\text { satellite data }\end{array}$ & $\begin{array}{l}\text { Feature identification and ortho-mapping, } \\
\text { with increasingly short return periods } \\
\text { combined with high resolution of up to } 40 \\
\mathrm{~cm} \text { from low earth orbit, optical data } \\
\text { provides synoptic, accurate and fresh } \\
\text { context mapping of an entire site at very } \\
\text { low cost per square km generally from a } \\
\text { single shot. } \\
\text { Spectral classification - contaminated } \\
\text { land indicators such as vegetation die } \\
\text { back and water discolouration can be } \\
\text { determined from these. } \\
\text { Change detection - high, almost daily } \\
\text { revisit of sites affords opportunity for } \\
\text { monitoring landscape change for } \\
\text { detecting and mapping rapidly evolving } \\
\text { processes and activities. }\end{array}$ & $\begin{array}{l}\text { Detection of leaching of tailings from the } \\
\text { structure indicated by declining vegetation } \\
\text { health or increasing iron oxide traces. } \\
\text { Changes in moisture content of the dam } \\
\text { body soil which could indicate future } \\
\text { structural problems. } \\
\text { Changes in seepage rates which could } \\
\text { indicate internal erosion issues within the } \\
\text { dam body. } \\
\text { Beach width measurement. A beach is } \\
\text { formed as a tailings deposit and it keeps } \\
\text { the supernatant pond away from the dam } \\
\text { and the phreatic surface low, thus } \\
\text { reducing the risk of failure. } \\
\text { Slope failure detection, relevant } \\
\text { especially for closed sites, using a } \\
\text { combination of parameters (e.g. soil } \\
\text { moisture, muddiness, surface features, } \\
\text { slope change). }\end{array}$ \\
\hline $\begin{array}{l}\text { Global } \\
\text { Navigation } \\
\text { Satellite System } \\
\text { (GNSS) }\end{array}$ & $\begin{array}{l}\text { GNSS can be used to autonomously } \\
\text { compute three-dimensional motion } \\
\text { vectors of a number of points using } \\
\text { standard in-situ located GNSS receivers } \\
\text { to an accuracy of a few millimetres. }\end{array}$ & $\begin{array}{l}\text { Monitoring of abnormal deformation of } \\
\text { key specific points of the structure in real } \\
\text { time (requires a base station to be } \\
\text { installed). }\end{array}$ \\
\hline $\begin{array}{l}\text { Global weather } \\
\text { forecasting } \\
\text { models }\end{array}$ & $\begin{array}{l}\text { Forecasts of climate variables such as } \\
\text { rainfall and temperature from, for } \\
\text { example, the European Centre for } \\
\text { Medium-range Weather Forecasting } \\
\text { (ECMWF) or the National Oceanic and } \\
\text { Atmospheric Administration (NOAA). }\end{array}$ & $\begin{array}{l}\text { Forecasts of runoff that can be used to } \\
\text { assess the probability of overtopping, or a } \\
\text { potential dangerous increase in the } \\
\text { moisture content of the dam body that } \\
\text { could affect stability. }\end{array}$ \\
\hline
\end{tabular}



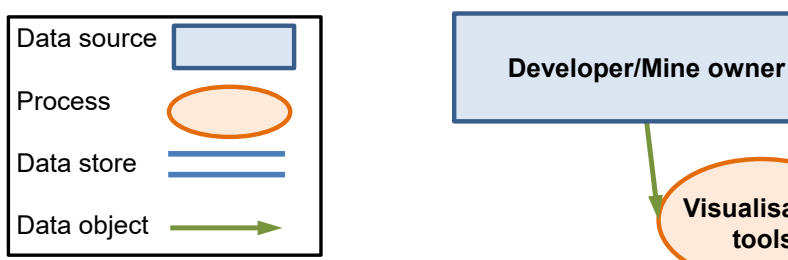

\section{End users}

(mining company, environmental regulator, NGOs)

\section{$\longrightarrow$}

Earth observation (EO) data - Optical

Feature identification and ortho-mapping Spectral classification Change detection Digital Terrain Model (DTM)

Earth observation
data - Synthetic
Aperture Radar
(SAR)

Ground motion and deformation detection Coherence/amplitude change detection

Water extent mapping

Global Navigation Satellite Systems (GNSS)

\section{Medium-range weather forecasts}

Short-term (i.e. up to 15 day lead times) climate forecasts at a $9 \mathrm{~km} \times 9 \mathrm{~km}$ grid resolution

Real time motion detection

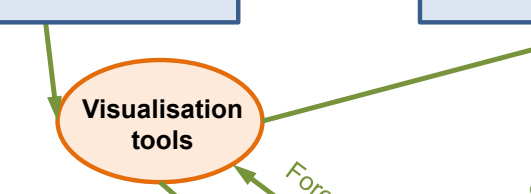
regulator, NGOs)

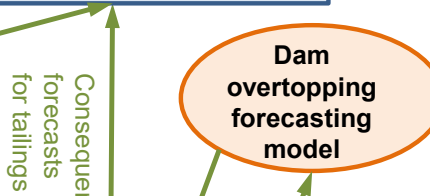

Probability of pollution incident model
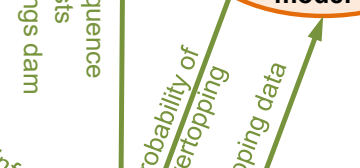
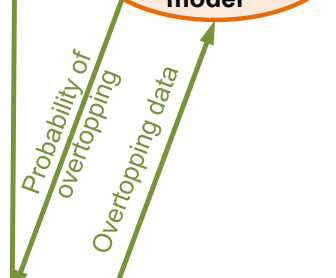

Database for storage and integration of

(a)
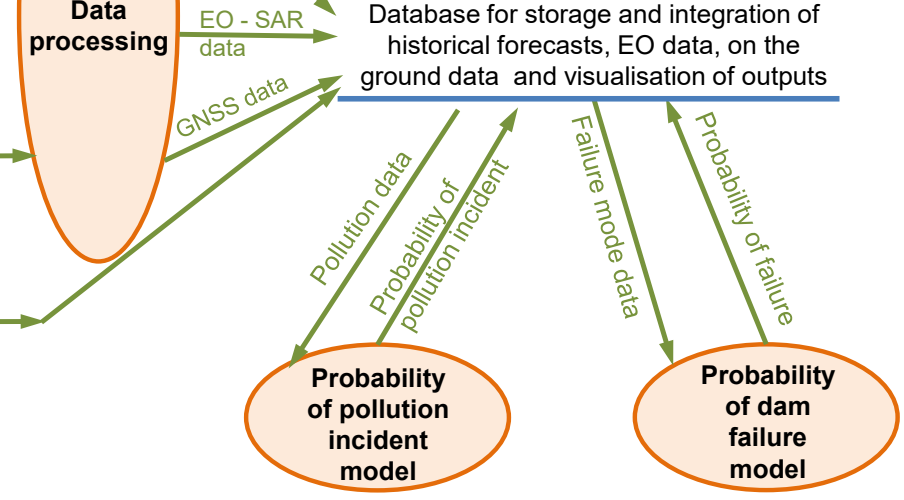

Figure 3 Diagram showing the data flows for an EO-based system for monitoring tailings dams 


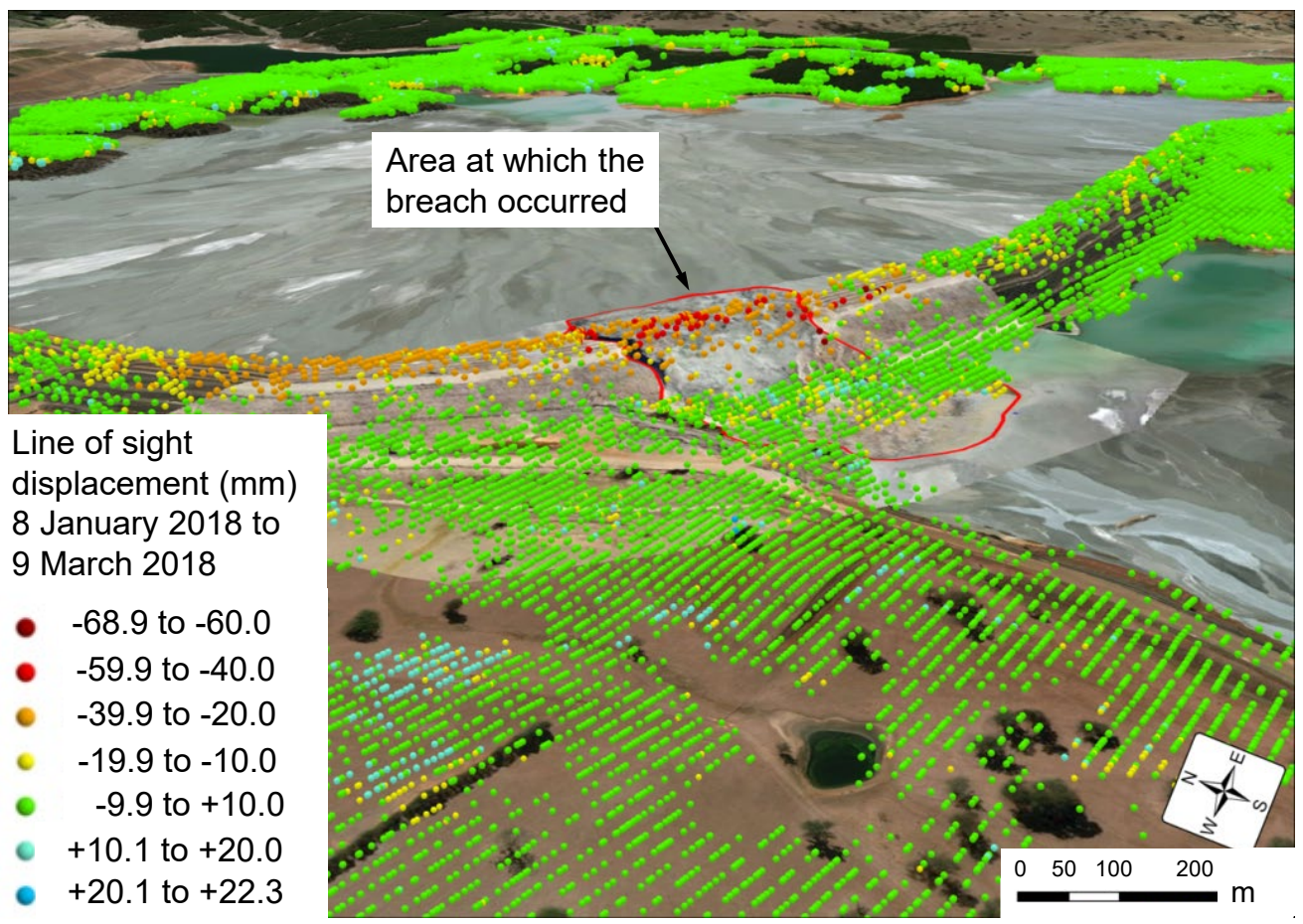

View A: Cumulated displacement field measured before the event using InSAR superimposed on the aerial image of the aftermath the dam breach

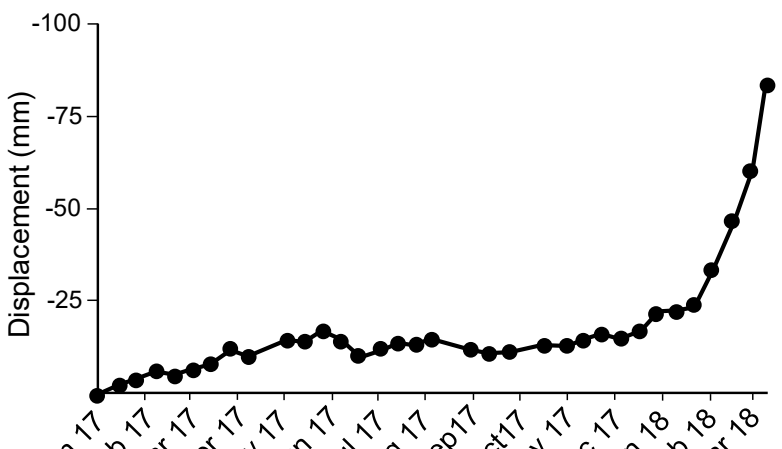

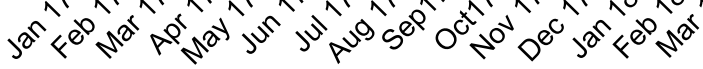

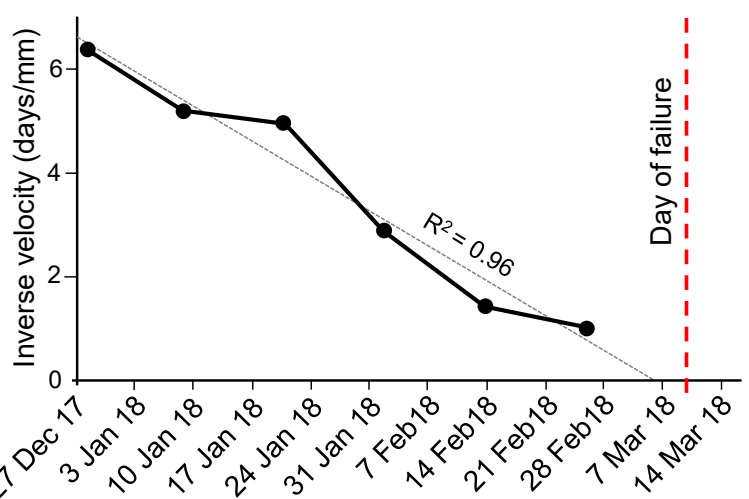

View B: Time series of the displacement of the View C: Inverse velocity of the dam slope vs date dam

(Source: [65])

Figure 4 Use of InSAR satellite data to demonstrate that EO-based data could have been used to help detect the failure of a tailings dam at the Cadia gold mine, Australia on 9 March 2018 


\subsection{The challenges and costs of using satellite-based technology to monitor tailings dams}

The use of satellite-based technologies to monitor tailings dams is not without its challenges and should be seen as complementary to existing in-situ surveillance techniques, where these are employed, and providing a method of overseeing abandoned facilities which are not currently being monitored. This section briefly describes some of the constraints and costs of using satellite based technology in this domain.

\subsubsection{Detecting deformations in structures using Interferometric Synthetic Aperture Radar (InSAR) data}

There are satellites that offer freely available InSAR data globally (e.g. Sentinel-1A) that can be used to measure deformations in structures. InSAR has been used to monitor subsidence in buildings and opencast mines for over 10 years [67]. The shorter the revisit time of the satellite the more accurate the analysis of the temporal evolution of the deformation of a structure is likely to be. InSAR data has a sufficiently frequent repeat cycle to allow the deformation in tailings dams to be monitored (e.g. Sentinel-1A has a revisit time of 12 days) [68]. All satellites equipped with InSAR sensors orbit the earth on a near-polar orbit at an altitude between $500 \mathrm{~km}$ to $800 \mathrm{~km}$, travelling from the north pole towards the south pole for half of their trajectory (the descending orbit) and the other half travelling from the south towards the north pole (the ascending orbit) [68]. The same area is revisited along the two orbits allowing ascending and descending data to be collected over the same area.

InSAR is reliant on radar signals that can be characterised by their amplitude and phase (see Figure 5). The phase of the radar is related to the distance between the sensor and area of interest [68]. InSAR measures the signal phase change between two images acquired over the same area, at different times. When a point on the ground moves, the distance between the sensor and the point changes and so the phase value recorded by the sensor is also altered as well. By processing InSAR datasets, the deformation of a surface over a period of time can be measured. This is shown in Figure 5. The temporal resolution of the displacement data depends on the revisit period of the satellite. 


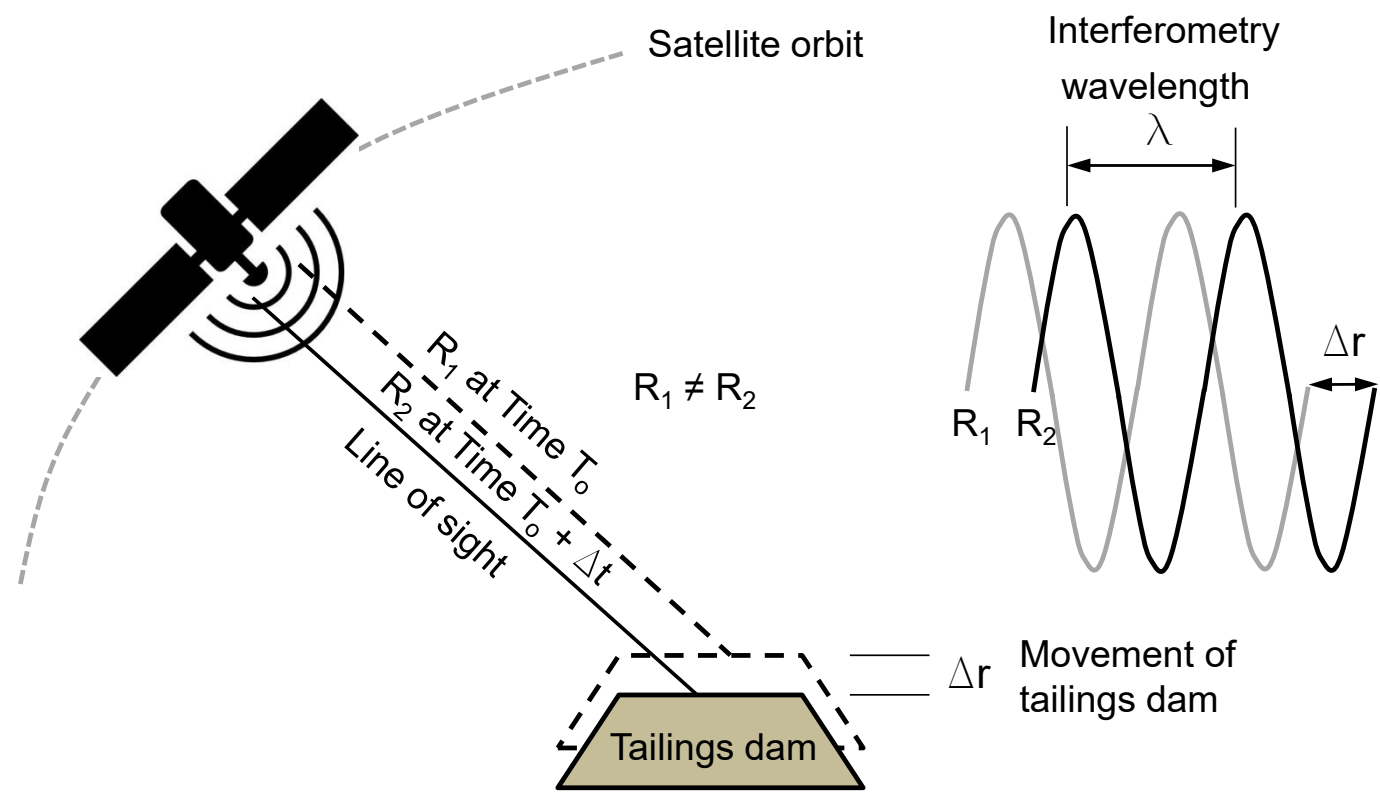

\section{Figure 5 Use of InSAR to measure the movement of tailings dams}

One of the challenges of using InSAR is that it is only sensitive to displacements that have a component in the direction of the line of sight (LOS) (see Figure 5), The LOS depends on the orientation of the satellite and the incidence angle of the radar beam. The steeper the incidence angle the better the sensitivity of the InSAR is to vertical displacements. Looking towards the west, a descending orbit gives mainly non-distorted coverage in west facing slopes, and an ascending orbit covers mainly east facing slopes. Sensitivity is very low in cases where the actual surface displacement vector is near perpendicular to the LOS. Owing to the north-south orbit direction, the sensitivity to surface displacement in this plane is near zero [68].

InSAR measures the signal phase change between two images acquired over the same area, at different times. When a point on the ground moves, the distance between the sensor and the point changes and so the phase value recorded by the InSAR sensor will change. However, deformation of the surface is only one of the components of the measured phase difference. In addition, there are atmospheric effects and other noise contributions that have to be removed first before the movement of a point on a structure can be calculated [68].

The InSAR signal can also be affected by what is known as "phase decorrelation" owing to changes in position of individual scatters within what is known as the resolution cell ${ }^{5}$ [69]. Generally decorrelation occurs owing to either SAR imaging geometric effects (spatial decorrelation), or temporal backscattering changes (temporal decorrelation) [69]. Spatial decorrelation is related to the baseline between the sensor at the different acquisitions. Temporal decorrelation is due to changes in the properties of the surface between the revisit, for example, caused by moving parts of vegetation, significant changes of water content or soil properties [69]. Hence, if there is vegetation on the surface of the structure or spatial decorrelation of the InSAR signal then the accuracy of the deformation of the tailings dam is likely to be low.

\footnotetext{
${ }^{5}$ The satellite measures the deformation that occurs within a certain resolution cell. For a high resolution one this is typically $1 \mathrm{~m}$ to $2 \mathrm{~m}$ and for a low resolution this is typically $2 \mathrm{~m}$ to $3 \mathrm{~m}$ [68].
} 
In terms of costs, Sentinel-1A data are freely available. InSAR data from other satellites, such as COSMOSkyMed, provide more accurate measurements of deformation; however, there is a cost related to obtaining these data which can run to thousands of US dollars dependent on the area to be monitored. Tomás et al. recently performed a cost analysis comparing InSAR with other conventional techniques for monitoring subsidence in mining areas [69]. It was found that the use of InSAR provides good value for money compared to other techniques owing to its higher data acquisition frequency and spatial coverage and its lower annual cost per measurement point per square kilometre [69].

\subsubsection{Detecting movement using Global Navigation Satellite System (GNSS)}

GNSS is a system that uses satellites to provide autonomous geo-spatial positioning. It allows small electronic receivers to determine their location (longitude, latitude, and altitude/elevation) with a high degree of accuracy using time signals transmitted along a line of sight by radio from satellites. GNSS equipment provides an accuracy of. within one or two millimetres [70]. However, GNSS equipment is expensive typically costing between US $\$ 60,000$ and US $\$ 120,000$ to install in remote locations. In addition, the measurement of structural movements is limited to points where the GNSS equipment is located and ground-based instruments can be vulnerable to vandalism and theft.

\subsubsection{Optical satellite information to monitor pollution}

There are a number of freely available optical satellite products that can be used to monitor pollution (e.g. Sentinel 2). For example, the iron oxide content of the soil can be monitored from space. An increase in iron oxide content in the proximity of a tailings dam can denote pollution from a number of sources including acid mine drainage. Vegetation indices based on optical-based satellite data can be used to monitor pollution by heavy metals by mapping vegetation stress [71]. This is because vegetation stress often results in a change in its spectral signature [68].

Optical satellite imagery has its limitation, for example, clouds may obstruct the site during the period that the satellite is overhead. In addition, such methods are limited to detecting relatively large areas where pollution or leaching of fluids from a tailings dam has occurred. An area of several square metres would need to be affected before the leaching of pollutants could be identified. The temporal resolution of days rather than a few hours may also be a constraint for some users. However, the use of optical satellite imagery provides a method of monitoring abandoned tailings dams and could provide regulators with an oversight of which tailings dams are causing the most pollution. 


\section{Peru case study}

The mineral industry provides a major source of economic growth in Peru's national development. In the recent past in Peru there have been several significant tailings dam incidents including:

- In 1993 the tailings dam at Marsa failed by overtopping resulting in six deaths;

- In 1996 a tailings dam at Amatista Nazca failed as a resulted of liquefaction releasing more than $300,000 \mathrm{~m}^{3}$ of tailings that contaminated farmers' land;

- In 2010 the tailings dam at Huancavelica failed releasing $21,400 \mathrm{~m}^{3}$ of tailings leading to the contamination of the Escalera and Opamayo Rivers up to $110 \mathrm{~km}$ downstream.

It is estimated that Peru has some 200 operating mines and many major mining projects are currently waiting to be developed. Most of these operational mines have tailings dams and in addition there are also thousands of abandoned mines throughout the country [72].

As part of a project funded by UK Space Agency's International Partnership Programme the use of satellitebased information to set up a tailings dam monitoring system, known as DAMSAT, is being piloted in some of the poorest provinces of Peru such as the Cajamarca Region [73]. Cajamarca is home to numerous small and large mines including the fourth largest gold mine in the world, as well as a number of large copper mines. The work on an EO-based monitoring system is currently being piloted at two Peruvian sites, one of which is in Cajamarca.

As part of the work a range of Peruvian stakeholders, including the Ministry of the Environment, Ministry of Energy and Mines, the National Water Authority, as well as NGOs, were engaged with to elicit their challenges and requirements related to the monitoring of tailings dams. Many of these organisations reported that they have limited resources and are not able to visit sites frequently, This makes it challenging for them to monitor tailings dams effectively. It was also reported that pollution from orphaned tailings dams in remote areas of Peru often affects downstream communities. The stakeholder engagement was part of the process of developing a user requirements document for DAMSAT. Peruvian stakeholders recognised that a satellite-based monitoring system could assist them with the following:

- Enhanced monitoring of operational tailings dams in Peru via the assessment of the physical stability of structures and potential pollution incidents;

- Monitoring of decommissioned and orphaned tailings dams;

- Quantification of the risks posed by tailings dams;

- Improvements in the accessibility of information on tailings dams to regulators.

The range of services discussed with the Peruvian stakeholders and expected to be offered by the DAMSAT system are outlined in Table 3. Users will mainly interact with the EO-based system through a web browser interface. This will use a map to show an overview of the status of all the points of interest on the tailings dam, and will allow users to investigate the detailed information available for each point. The system may provide methods for alerting users to significant events by sending email or SMS messages. An example of a user interface with a traffic light based warning system is shown in Figure 6. It is proposed that DAMSAT will offer two levels of service. Level 1 is based on freely available satellite-based information whilst Level 2 uses more accurate data, in terms of temporal or spatial resolutions, for which there is sometimes an associated acquisition cost. Table 4 provides an overview of the Level 1 and 2 information that will be used in DAMSAT together with approximate costs to obtain it. 
Table 3: Services provided by the DAMSAT satellite-based tailings dam monitoring system

\begin{tabular}{|c|c|}
\hline Service & Use \\
\hline $\begin{array}{l}\text { Current and historical } \\
\text { satellite imagery }\end{array}$ & $\begin{array}{l}\text { Allows a manual inspection of points of interest on the dam. Allows a comparison of the } \\
\text { current image with historical images to assist users to detect changes that occur on site. }\end{array}$ \\
\hline $\begin{array}{l}\text { Physical stability } \\
\text { monitoring based on } \\
\text { InSAR data and GNSS }\end{array}$ & $\begin{array}{l}\text { Provides an indication of displacement based on a three category classification: (1) below } \\
\text { threshold or undetectable movement; (2) possibly significant movement detected; (3) } \\
\text { likely significant movement detected. }\end{array}$ \\
\hline $\begin{array}{l}\text { Chemical stability - } \\
\text { leaching }\end{array}$ & $\begin{array}{l}\text { Analysing sequences of optical data for signs of increased iron oxide concentrations can } \\
\text { be used as a proxy for pollution occurring. }\end{array}$ \\
\hline $\begin{array}{l}\text { Chemical stability - } \\
\text { vegetation }\end{array}$ & $\begin{array}{l}\text { Monitoring the "health" of vegetation as an indicator of potential leaching or pollution } \\
\text { emanating from a site. }\end{array}$ \\
\hline Forecasting & Forecasting of possible dam overtopping or breach driven by weather forecasts. \\
\hline Virtual supervisor & Automated interpretation of all inputs. \\
\hline Impact modelling & $\begin{array}{l}\text { Modelling of the consequence of dam overtopping or breaching in terms of loss of life or } \\
\text { risks to buildings. }\end{array}$ \\
\hline
\end{tabular}

Table 4: Level 1 and 2 information and their associated costs to be used by DAMSAT

\begin{tabular}{|c|c|c|c|}
\hline \multicolumn{2}{|l|}{ Level 1} & \multicolumn{2}{|l|}{ Level 2} \\
\hline Source of information & $\begin{array}{l}\text { Indicative costs of } \\
\text { obtaining information } \\
\text { and/or installation of } \\
\text { equipment (US\$) }\end{array}$ & Source of information & $\begin{array}{l}\text { Indicative costs of } \\
\text { obtaining information } \\
\text { and/or installation of } \\
\text { equipment (US\$) }\end{array}$ \\
\hline $\begin{array}{l}\text { Sentinel } 1 \text { InSAR data on a } 5 \mathrm{~m} \\
\times 20 \mathrm{~m} \text { grid to measure } \\
\text { deformations of a few } \\
\text { millimetres }\end{array}$ & Free & $\begin{array}{l}\text { COSMO-SkyMed InSAR data } \\
\text { on a } 5 \text { m grid to measure } \\
\text { deformations of a few } \\
\text { millimetres }\end{array}$ & $\begin{array}{l}\text { US } \$ 1,200 \text { per } \mathrm{km} 2 \text { per } \\
\text { annum }\end{array}$ \\
\hline $\begin{array}{l}\text { Sentinel } 2 \text { optical imagery on a } \\
10 \mathrm{~m} \text { grid for monitoring the } \\
\text { health of vegetation and the } \\
\text { leaching of chemicals }\end{array}$ & Free & $\begin{array}{l}\text { PeruSat- } 1 \text { optical imagery on } \\
\text { a } 0.7 \mathrm{~m} \text { grid for monitoring the } \\
\text { health of vegetation and the } \\
\text { leaching of chemicals }\end{array}$ & $\begin{array}{l}\text { Free to Peruvian } \\
\text { government } \\
\text { organisations and NGOs }\end{array}$ \\
\hline $\begin{array}{l}\text { National Oceanic and } \\
\text { Atmospheric Administration } \\
\text { Global Forecast System (GFS) } \\
\text { to provide weather forecasts } \\
\text { with a } 10 \text { day lead time }\end{array}$ & Free & $\begin{array}{l}\text { European Centre for Medium } \\
\text { Range Weather Forecasts } \\
\text { (ECMWF) to provide weather } \\
\text { forecasts with up to a } 15 \text { day } \\
\text { lead time }\end{array}$ & $\begin{array}{l}\text { Dependent on the } \\
\text { variables required } \$ 2,000 \\
\text { to } \$ 10,000 \text { per annum }\end{array}$ \\
\hline GNSS based monitoring & Not available & GNSS based monitoring & $\begin{array}{l}\$ 60,000 \text { to } \$ 120,000 \\
\text { depending on the } \\
\text { number and type of } \\
\text { installations of GNSS } \\
\text { equipment }\end{array}$ \\
\hline
\end{tabular}

Note: The costs in this table refer to the costs of obtaining data and installing equipment not the costs of running the DAMSAT system. 


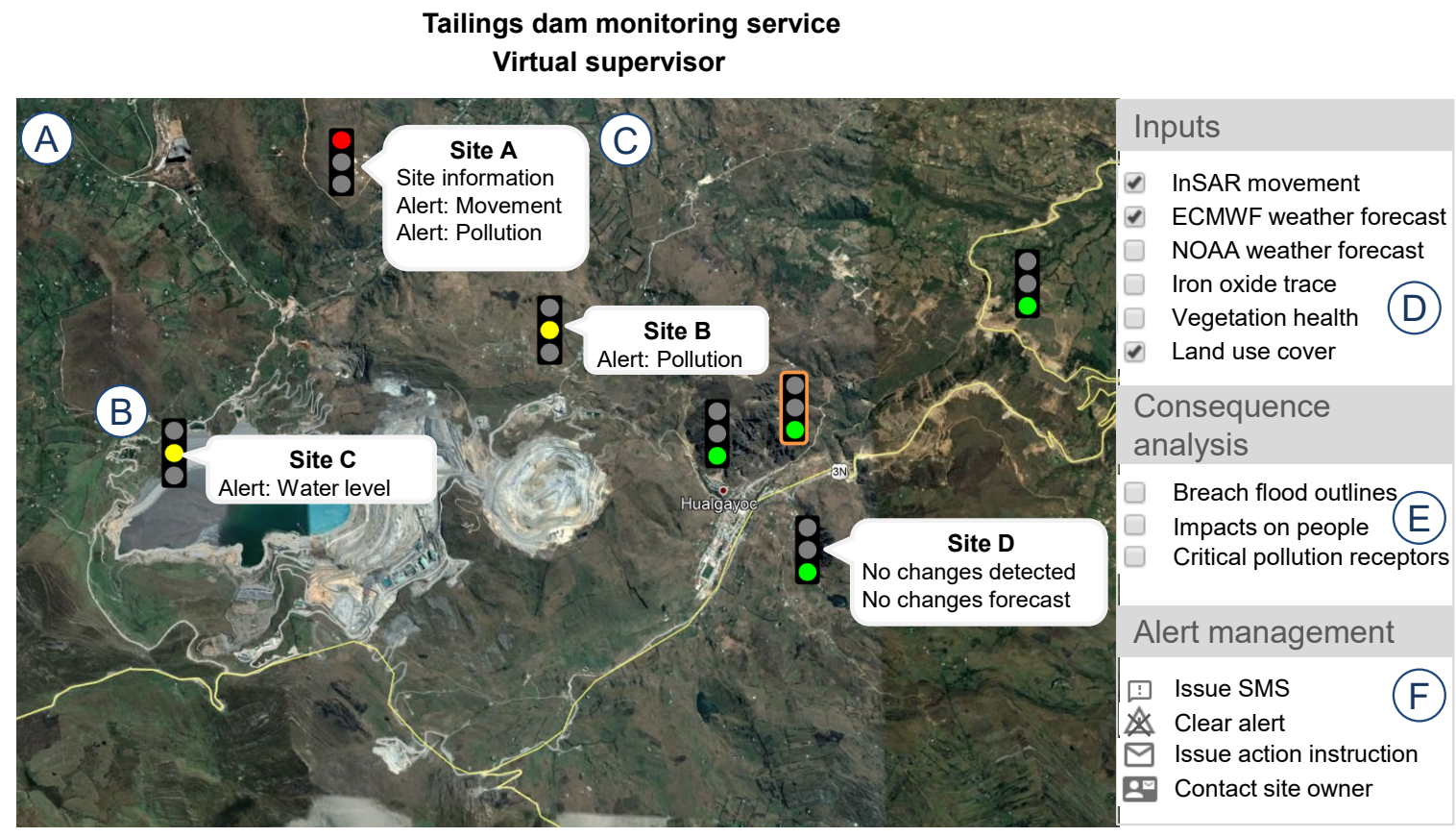

Notes: A. Browser map-based interface

D. List of data services to which the organisation has subscribed

B. Traffic light status indicators for sites of interest

C. Popups indicate cause of alert and link to details

E. Available consequence data to overlay on map

Figure 6 Diagram showing a prototype user interface for an EO-based system for monitoring tailings dams in Peru

\section{Conclusions}

There has been a systemic failure by the mining industry, governments and civil society to manage the safety of tailings dams. This paper has reviewed the potential of satellite-based data to reduce the probability of tailings dams failures and the subsequent consequences of failures where, in some cases, the cost of the clean-up of has run to billions of US dollars [7] [57], led to hundreds of lives being lost and caused untold environmental damage. These risks constitute a considerable incentive for mining companies and governments to demonstrate measures which will help to mitigate this situation. The paper has explained how a new collaborative research programme is developing an EO-based service that could allow the cost effective monitoring of tailings dams over wide geographic areas and in remote locations. Further, this service could also help to forecast potentially risk inducing behaviours of these structures several weeks in advance, allowing timely preventative interventions to be made. The pilot application for the EO tool this research has developed is based in Cajamarca region of Peru. The objective of this pilot to help demonstrate benefits that can be derived from remote satellite-based surveillance techniques and encourage more active management of the risks associated with tailing dams.

Despite a recent fall in commodity prices, the market capitalisation of the top 40 global mining companies is some US $\$ 700$ billion [4]. There is a growing pressure from governments, the public and a range of other stakeholders for mining companies to improve their green credentials for the good of society and to contribute to countries meeting their Sustainable Development Goals. Recently the mining sector has seen the end of the commodity super-cycle (the rise and fall of many physical commodity prices which occurred 
during the first two decades of the 2000s); lower ore prices; increased demand to manage environmental risk and social licence; an improving investor awareness of environmental risks; and more remote and/sensitive environments for new mining projects [74]. Together these factors are conspiring to push mining firms to urgently find the most cost effective means of managing and reporting their environmental and social performance. The development of an EO-based method for monitoring tailings dams and mines could give mining companies a more efficient and cost effective way of monitoring their operations.

Early results of this work indicate that the use of the DAMSAT tool and platform to use EO-based data to reduce the probability of tailings dams failure is of interest to regulators and civil society, with developing interest from large-multinational mining companies and a diversity of other stakeholders including investors and the insurance sector. Beyond the scientific integration of EO data into a risk-monitoring tool, this research advances our knowledge about how the use of transparency as a mechanism for improved sustainable development can help develop the participation of broader civil society and potentially create pathways to engagement in the extractive-state development process. In this way, not only can governments improve their ability to oversee mining companies, but civil society can also help to hold the government accountable. Emerging economies that are subject to political instability, as many resource-driven economies are, stand to benefit quickly from the use of an EO-based tool that advances transparency and helps leapfrog years of fiscal and human capital development. The work carried out to date indicates that this form of tailings dam monitoring is an achievable first step to claim aspects of this satellite technology for public use and furthering, rather than limiting, the accessibility of knowledge of the mining sector for decision-making that could help improve development outcomes.

There are plans to extend the pilot use of the EO to more mining areas within Peru and globally. As the use of the tool is scaled up its agility for use in diverse sites around the world will be continually improved. Further research will be necessary to best support the integration of EO based tools into risk management practices shared across diverse organisations. Moreover, this technology offers only one facet of environmental and social risk reduction that EO technologies could potentially help address and there is considerable scope for future research into its application for other challenges such as the remote monitoring of water retaining dams, flood defences and other linear infrastructure including pipelines and railway embankments.

\section{Acknowledgements}

The authors would like to acknowledge that this work was made possible as part of the DAMSAT project funded by a grant from the UK Space Agency's International Partnership Programme. The objective of the work is to minimise the risk of tailings dams failures in Peru through the use of remote sensing data.

The team working on the project is led by HR Wallingford and comprises Telespazio VEGA UK, Siemens Corporate Technology, Smith School of Enterprise and the Environment, Oxford University, Satellite Application Catapult, Oxford Policy Management, Regional Government of Cajamarca, Peruvian National Water Authority, Ciemam SAC, Peruvian National Foundation for Hydraulics, Peru's National Institution of Engineers, Department of Cajamarca, School of Hydraulic Engineering, National University of Cajamarca.

More information on this work is available from www.damsat.org 


\section{References}

[1] International Council of Mining and Metals (ICMM) (2018) Mining with principles: The role of mining in national economies, Mining Contribution Index 2018, 4th Edition

[2] World Bank (2002) Mining and development: Treasure or trouble? Mining in developing countries, Washington DC, USA. Available at: http://siteresources.worldbank.org/INTOGMC/Resources/treasureortrouble.pdf [Accessed: 12 February 2019]

[3] Ericsson, M. and Löf, O. (2017) Mining's contribution to low- and middle income economies, WIDER Working Paper 2017/148, United Nations World Institute for Development Economic Research. Available at: https://www.wider.unu.edu/publication/mining\%E2\%80\%99s-contribution-low-and-middle-income-economies [Accessed: 12 February 2019]

[4] PWC (2018) Mine 2018: Tempting times. Available at: https://www.pwc.com/id/mine-2018 [Accessed: 12 February 2019]

[5] United Nations (UN) (2017) Earth observations for official statistics, Satellite imagery and geospatial data task team report, 5 December 2017 Available at: https://unstats.un.org/bigdata/taskteams/satellite/UNGWG Satellite Task Team Report WhiteCover.pdf [Accessed: 15 February 2019]

[6] Thomson Reuters ·(2019) Three Brazil mining company employees, two contractors arrested in dam disaster, CBC News, CBC 29 January 2019, Available at: https://www.cbc.ca/news/world/brazil-damdisaster-mining-arrests-1.4996923 [Accessed: 17 February 2019]

[7] Bowker, L.N. and Chambers, D.M. (2017) In the dark shadow of the supercycle tailings failure risk and public liability reach all-time highs, Environments 2017, 4, 75; doi:10.3390/environments 4040075

[8] Kossoff, D., Dubbin, W.E., Alfredsson, M., Edwards, S.J., Macklin, M.G. and Hudons-Edwards, K.A. (2014) Mine tailings dams: characteristics, failure, environmental impacts and remediation. Applied Geochemistry 51 229-245

[9] Barrera, S., Cacciuttolo, C. and Caldwell, J. (2015) Reassessment of best available tailings management practices, Proceedings Tailings and Mine Waste 2015, Vancouver, BC, Canada, 26 to 28 October 2015 Available at: https://open.library.ubc.ca/media/download/pdf/59368/1.0319135/5 [Accessed 29 May 2019]

[10] Yilmaz, E. and Fall, M. (2017) Paste tailings management, Springer International Publishing, Geneva, Switzerland, First edition ISBN 978-3-319-39680-4

[11] Martin, T.E., Davies, M.P., Rice, S., Higgs, T. and Lighthall, P.C. (2002) Stewardship of tailings facilities, April 2002, International Institute for Environment and Development Available at: https://pubs.iied.org/pdfs/G01027.pdf [Accessed 29 May 2019]

[12] Priscu, C. (1999) Behaviour of mine tailings dams under high tailings deposition rates, A thesis submitted to the Faculty of Graduate Studies and Research in partial fulfilment of the degree of Doctor of Philosophy Available at: https://www.collectionscanada.gc.ca/obj/s4/f2/dsk1/tape8/PQDD 0024/NQ50240.pdf [Accessed 29 May 2019] 
[13] Zardari, M.A. (2011) The stability of tailings dams ISBN 978-91-7439-245-6 Available at: https://www.diva-portal.org/smash/get/diva2:991436/FULLTEXT01.pdf [Accessed 29 May 2019]

[14] Bhanbhro, R., Knutsson, R., Rodriguez, J., Edeskär, T. and Knutsson, S. (2013) Basic description of tailings from Aitik focusing on mechanical behaviour, International Journal of Emerging Technology and Advanced Engineering, Volume 3, Number 12, pp65-69

[15] Rico, M., Benito, G., Salgueiro, A.R., Díez -Herrero, A. and Pereira, H.G. (2008) Reported tailings dam failures: a review of the European incidents in the worldwide context, Journal of Hazardous Material, 152, pp. 846-852

[16] Azam, S. and Li, Q. (2010) Tailings dam failures: A review of the last one hundred years, Geotechnical News, December 2010, pp50-53, Available at: http://ksmproject.com/wp-content/uploads/2017/08/TailingsDam-Failures-Last-100-years-Azam2010.pdf [Accessed: 18 February 2019]

[17] Roche, C., Thygesen, K. and Baker, E. (Eds.) (2017) Mine tailings storage: Safety is no accident. A UNEP rapid response assessment. United Nations Environment Programme and GRID-Arendal, Nairobi and Arendal, www.grida.no ISBN: 978-82-7701-170-7 Available at: https://gridarendal-websitelive.s3.amazonaws.com/production/documents/:s document/371/original/RRA MineTailings lores.pdf?1510 $\underline{606693}$ [Accessed: 18 February 2019]

[18] National Inventory of Dams (NID) (2019) National inventory of dams, Available at: https://nidtest.sec.usace.army.mil/ [Accessed: 14 February 2019]

[19] Martin, T.E. and Davies, M.P. (2000) Trends in the stewardship of tailings dams. In: Proceedings of Tailings and Mine Waste 2000, Fort Collins, January, Balkema Publishers, pp. 393-407

[20] Wei, Z., Yin, G., Wang, J.G., Wan, L. and Li, G. (2013) Design, construction and management of tailings storage facilities for surface disposal in China: Case studies of failures, Waste Management \& Research 31(1) $106-112$

[21] China Daily (2011) Alarm over tailings' effects on rivers Available at: http://www.chinadaily.com.cn/cndy/2011-07/29/content 13006210.htm [Accessed: 21 February, 2018]

[22] Neelin, J.D., Sahany, S., Stechmann, S.N. and Bernstein, D.N. (2017) Global warming precipitation accumulation increases above the current-climate cutoff scale Proceedings of the National Academy of Sciences February 2017, 114 (6) 1258-1263; doi: 10.1073/pnas.1615333114

[23] Bloomberg (2019) Vale analysts see charges, lawsuits and halts undermining stock, 28 January 2019. Available at: http://www.mining.com/web/vale-analysts-see-charges-lawsuits-halts-undermining-stock/ [Accessed: 12 February 2019]

[24] Bowker, L.N. and Chambers, D.M. (2015) The risk, public liability, and economics of tailings storage facility failures. Available at: http://csp2.org/files/reports/Bowker\%20\%26\%20Chambers\%20-\%20RiskPublic\%20LiabilityEconomics\%20of\%20Tailings\%20Storage\%20Facility\%20Failures\%20\%E2\%80\%93\%2023Jul15.pdf [Accessed: 12 February 2019]

[25] Estevez, D. (2017) Billionaire German Larrea's Grupo Mexico failed victims in mining disaster, UN says, Forbes 27 July 2017 Available at: https://www.forbes.com/sites/doliaestevez/2017/07/27/un-singles-outtycoon-german-larreas-grupo-mexico-for-unfulfilled-pledge-in-ecological-disaster/\#670e756d1506 [Accessed: 12 February 2019] 
[26] Glotov, V.E., Chlachula, J., Glotova, L.P. and Little, E. (2018) Causes and environmental impact of the gold-tailings dam failure at Karamken, the Russian Far East, Engineering Geology 245 (2018) 236-247

[27] The Guardian (2010) Hungary declares a state of emergency after sludge disaster, 5 October 2010. Available at: https://www.theguardian.com/world/2010/oct/05/hungary-sludge-disaster-state-of-emergency [Accessed: 12 February 2019]

[28] Fernandes, G.W., Goulart, F.F., Ranieri, B.D., Coelho, M.S, Dales, K., Boesche, N., Bustamante, M., Carvalho, F.A., Carvalho, D.C., Dirzo, R., Fernandes, S., Galetti, P.M., Millan, V.E.G., Mielke, C., Ramirez, J.L., Neves, A., Rogass, C., Ribeiro, S.P., Scariot, A., and Soares-Filho, B. (2016) Deep into the mud: Ecological and socio-economic impacts of the dam breach in Mariana, Brazil, Natureza \& Conservação, Volume 14, Issue 2, 2016, pp35-45, ISSN 1679-0073

[29] Fuller, M. and Jacobs, M. (2015) Tailings stewardship - "Genuine" corporate responsibility, Tailings and Mine Waste 2015 Conference, Vancouver, British Columbia, Canada, 2015

[30] Reuters (2015) Charges laid regarding October 2013 Obed Mountain Coal mine spill, Reuters, 16 October 2015. Available at: https://www.marketwatch.com/press-release/charges-laid-regarding-october2013-obed-mountain-coal-mine-spill-2015-10-16-171734056 [Accessed: 12 February 2019]

[31] Robson, P. (2017) The river is dead: The impact of the catastrophic failure of the Fundão tailings dam, October 2017. Available at: http://stop-mad-mining.org/wp-content/uploads/2015/10/Fundao-Report-Finallowres-2.pdf [Accessed: 12 February 2019]

[32] Willis Towers Watson (2016) Mining risk review 2016: Dealing with uncertainty. Available at: https://www.willis.com/naturalresources/pdf/MiningRiskReview2016.pdf [Accessed: 12 February 2019]

[33] Zvereva V.P., Krupskaya, L.T. and Malyuk, Y.A. (2013) The influence of Karamkenskoe deposit tailing dump on the region hydrosphere and the dump recultivation (Magadan Region) Russian, Journal of General Chemistry, 2013, Volume 83, No. 13, pp. 2694-2700

[34] International Commission On Large Dams ICOLD (2001) Tailings dams - Risk of dangerous occurrences, lessons learnt from practical experiences, Bulletin 121. Available at: http://www.unep.fr/shared/publications/pdf/2891-TailingsDams.pdf [Accessed: 11 February 2019]

[35] Lemphers, N. (2010) Could the Hungarian tailings dam tragedy happen in Alberta? 12 October 2010. Available at: www.pembina.org/blog [Accessed: 5 October 2017]

[36] Carmo, F.F., Kamino, L.H.Y., Junior, R.T., Campos, I.C., Carmo, F.F., Silvino, G., da Silva, K.J., de Castro, X., Mauro, M.L., Rodrigues, N., Miranda, M.P. and Pinto, C.E.F (2017) Fundão tailings dam failures: the environment tragedy of the largest technological disaster of Brazilian mining in global context Perspectives in Ecology and Conservation, Vol. 15. Number 3.July - September 2017 pp141-244

[37] Hilson, G. (2006) Abatement of mercury pollution in the small-scale gold mining industry: Restructuring the policy and research agendas, Science of the Total Environment 362, pp1 - 14.

[38] Kalluri, B. and Mundoli, S. (2013) Gender equality and the extractive industry in the Lower Mekong Region published by Dhaatri Resource Centre for Women and Children, India doi: 10.13140/2.1.3743.0406

[39] Hill, C. and Newell, K. (2009) Women, communities and mining: The gender impacts of mining and the role of gender impact assessment, published by Oxfam Australia, Available at: 
https://newdemo.openrepository.com/bitstream/handle/2384/295288/ml-women-communities-mining011209-en.pdf?sequence $=1$ \&isAllowed=y [Accessed: 28 May 2019]

[40] Ward, B. (2011) Gender approaches for the extractive industry in Peru, World Bank Available at: http://documents.worldbank.org/curated/en/961001468058746060/Gender-sensitive-approaches-for-theextractive-industry-in-Peru-improving-the-impact-on-women-in-poverty-and-their-families-guide-forimproving-practice [Accessed: 12 February 2019]

[41] Losekann. C.(2016) After the world's largest mining disaster: what impacts? Who is affected?, Open Democracy / ISA RC-47: Open Movements,7 March

[42] Lumbroso, D. Sakamoto, D., Johnstone, W.M., Tagg, A.F. and Lence, B.J. (2011) The development of a Life Safety Model to estimate the risk posed to people by dam failures and floods, Dams and Reservoirs, The official journal of the British Dam Society, June 2011

[43] Lumbroso, D. and Davison, M. (2018) Use of an agent-based model and Monte Carlo analysis to estimate the effectiveness of emergency management interventions to reduce loss of life during extreme floods, Journal of Flood Risk Management, https://doi.org/10.1111//fr3.12230

[44] McClelland, D.M. and Bowles, D.S. (2002) Estimating life loss for dam safety risk assessment - A review and new approach, US Army Corps of Engineers, Institute for Water Resources, IWR report 02-R-3

[45] Llano-Serna, M., Williams, D. and Ruest, M. (2017) Analysis of tailings dam-break and run-out, Tailings $2017,4^{\text {th }}$ international seminar on tailings management, $12-14$ July 2017 , Santiago, Chile

[46] Akcil, A. and Koldas, S. (2006) Acid Mine Drainage (AMD): Causes, treatment and case studies. Journal of Cleaner production. Vol 14, Issues 12-13, 1139-1145

[47] Diamond, J. (2005) Collapse: How societies choose to fail or succeed, Published by the Penguin Group, New York, USA

[48] Bacsujlaky, M. (2004) Examples of modern mines that damaged rivers and fisheries, October 2004, published by Western Mining Action Network Available at: https://wman-info.org/wpcontent/uploads/2012/08/MinesRiversFish.pdf [Accessed: 18 February 2019]

[49] Achterberg, E. (1999) Impact of Los Frailes mine spill on riverine, estuarine and coastal waters in southern Spain, Water Resources, 33: 3387, doi:10.1016/S0043-1354(99)00282

[50] Byrne, P., Hudson-Edwards, K.A., Bird, G., Macklin, M.G., Brewer, P.A., Williams, R.D. and Jamieson, H.E. (2018) Water quality impacts and river system recovery following the 2014 Mount Polley mine tailings dam spill, British Columbia, Canada, Applied Geochemistry 91 (2018) 64-74; doi.org/10.1016/j.apgeochem.2018.01.012

[51] Prno, J. and Slocombe, D.S. (2012) Exploring the origins of 'social license to operate' in the mining sector: Perspectives from governance and sustainability theories. Resources policy, 37(3), pp.346-357.

[52] Martin, T.E. and Davies, M.P. (2000) Development and review of surveillance: Programs for tailings dams In Tailings Dams 2000 Proceedings. Association of State Dam Safety Officials. Las Vegas, USA

[53] Chen, G. and Lian, Z. (2018) The design and implementation of a displacement monitoring system for tailings dams, 2018 International Conference on Sensor Network and Computer Engineering (ICSNCE 2018), 27 to 29 April 2018, Xi'an, China 
[54] Mainali, G. (2006) Monitoring of tailings dams with geophysical methods, Luleå University of Technology Department of Chemical Engineering and Geosciences, Division of Ore Geology and Applied Geophysics Available at: http://citeseerx.ist.psu.edu/viewdoc/download?doi=10.1.1.544.4669\&rep=rep1\&type=pdf [Accessed: 17 February 2019]

[55] Franks, D. M. (2015) Mountain movers: Mining, sustainability and the agents of change, ISBN: 978-0415-71170-8, published by Routledge, New York, USA

[56] Phillips, D. (2016) Samarco dam collapse: One year on from Brazil's worst environmental disaster, 15 October 2016, The Guardian. Available at: www.theguardian.com/sustainablebusiness/2016/oct/15/samarco-dam-collapse-brazil-worst-environmental-disaster-bhp-billiton-vale-mining [Accessed: 6 December 2017]

[57] Moulton, E. (2016) BHP Billiton, Vale facing $\$ 7$ billion fine for Brazil's biggest environmental disaster, 10 February 2016, Available at: www.news.com.au [Accessed: 6 December 2017]

[58] Roche, C. and Judd, S. (2016) Ground truths: Taking responsibility for Australia's mining legacies, ISBN: 978-0-9946216-0-3 Available at: http://www.mpi.org.au/wp-content/uploads/2016/06/Ground-Truths2016-web.pdf [Accessed: 12 February 2019]

[59] Bridge, G. (2004) Contested terrain: Mining and the environment. Annual Review Environment Resources, 29, pp.205-259

[60] Aguirregabiria, V. and Luengo, A. (2016) A micro-econometric dynamic structural model of copper mining Decisions, Available at: http://aguirregabiria.net/wpapers/copper mining.pdf [Accessed: 11 February 2019]

[61] Chetty, P. (2013) Monitoring of mine tailings using satellite and lidar data, South African Surveying and Geomatics Indaba (SASGI) Proceedings 2013 - Stream 1 Available at: http://www.ee.co.za/wpcontent/uploads/2014/05/Prevlan-Chetty.pdf [Accessed: 21 February, 2018]

[62] Hui, S., Charlebois, L. and Sun, C. (2015) Real-time monitoring for structural health, public safety, and risk management of mine tailings dams, Canadian Journal of Earth Sciences Available at: https://tspace.library.utoronto.ca/bitstream/1807/82538/1/cjes-2017-0186.pdf [Accessed: 21 February 2019]

[63] Thomas, A. (2018) Cadia mine tailings failure: Digging deeper using earth observation data and InSAR, 17 July 2018, Available at: https://www.linkedin.com/pulse/cadia-mine-tailings-failure-digging-deeper-usingearth-adam-thomas/ [Accessed: 14 February 2019]

[64] McDevitt, A. (2017) Transparency and accountability initiatives in the extractives sector, K4D Helpdesk

Report. Brighton, UK: Institute of Development Studies. Available at: https://assets.publishing.service.gov.uk/media/59784da140f0b65dce000002/082-Transparency-andaccountability-in-extractive-industries.pdf [Accessed: 20 February 2019]

[65] Tre-Altimira (2018) Tailings dam failure Available at: https://site.tre-altamira.com/showcase/tailings-damfailure/ [Accessed: 15 February 2019]

[66] Carlà, T., Intrieri, E., Di Traglia, F., Nolesini, T., Gigli, G. and Casagli, N. (2017) Guidelines on the use of inverse velocity method as a tool for setting alarm thresholds and forecasting landslides and structure collapses, Landslides, April 2017, Volume 14, Issue 2, pp 517-534, https://doi.org/10.1007/s10346-016$\underline{0731-5}$ 
[67] Herrera, G., Tomás, R., Lopez-Sanchez, J.M., Delgado, J., Mallorqui, J.J., Duque, S., and Mulas, J. (2007) Advanced DInSAR analysis on mining areas: La Union case study (Murcia, SE Spain). Engineering Geology. 90 (3-4): 148-159. doi:10.1016/j.enggeo.2007.01.001

[68] Davids, C. and Rouyet, L. (2018) Remote sensing for the mining industry: Review report, Northern Research Industry Report ISBN: 978-82-7492-417-8 Available at: https://www.oulu.fi/sites/default/files/36/RESEM EOReview.pdf [Accessed 29 May 2019]

[69] Tomás, R., Romero, R., Mulas, J., Marturià, J.J., Mallorquí, J.J., Lopez-Sanchez, J.M., Herrera, G., Gutiérrez, F., González, P.J., Fernández, J., Duque, S., Concha-Dimas, A., Cocksley, G., Castañeda, C., Carrasco, D., and Blanco, P. (2014) Radar interferometry techniques for the study of ground subsidence phenomena: A review of practical issues through cases in Spain Environmental Earth Sciences. 71: pp163181

[70] Dardanelli, G., La Loggia, G., Perfetti, N., Capodici, F., Puccio, L., and Maltese, A. (2014). Monitoring displacements of an earthen dam using GNSS and remote sensing. In SPIE Remote Sensing, October, pp. 923928-923928

[71] Zhou, C., Chen, S., Zhang, Y., Zhao, J., Song, D. and Liu, D. (2018) Evaluating metal effects on the reflectance spectra of plant leaves during different seasons in post-mining areas, China, Remote Sensing 2018, 10(8), 1211; https://doi.org/10.3390/rs10081211

[72] Grupo de Formacion e Intervencion para el Desarrollo Sostenible (2015) Pasivos ambientales mineros en la region Cajamarca

[73] Hallman, B. and Olivera, R. (2015) Gold rush - How the World Bank is financing environmental destruction, Huffington Post Available at: http://projects.huffingtonpost.com/worldbank-evictedabandoned/how-worldbank-finances-environmental-destruction-peru [Accessed: 11 February 2019]

[74] Mothersole, J. (2015) The end of the commodity supercycle brings challenges and opportunities Available at: https://cdn.ihs.com/www/pdf/lHS-End-of-Commodity-Super-Cycle.pdf [Accessed: 8 May 2019] 